\section{Migrant Workers in} International Human

\section{Rights Law}

\section{Their Protection in Countries of Employment \\ RYSZARD CHOLEWINSKI}

This book examines the plight of migrant workers and their families in countries of employment and considers the protection they receive as aliens under international human rights law. It focuses on their economic, social, cultural, political, and residence rights - with a case-study of their legal place in Europe.

$1997 \$ 95.00$

\section{Making Commercial Law Essays in Honor of Roy Goode} Edited by ROSS CRANSTON

These essays were written in honor of Roy Goode, the Norton Rose Professor of English Law at

Oxford and highly esteemed commercial law scholar. This is a truly global collection that will interest scholars of commercial law worldwide, as well as practitioners of finance and international banking. $1997 \$ 115.00$

\section{Broadcasting Law and Fundamental Rights}

\section{RACHAEL CRAUFURD-SMITH}

Craufurd-Smith examines changes in both the structure of the broadcasting industry and the perceptions of its role in society. Also, in studies from Italy, France, and Britain, she explores legal challenges to the monopoly position of key broadcasters while pondering the implications for freedom of expression and the future of the industry.

$1997 \$ 85.00$

\section{Implementing the Uruguay Round}

Edited by JOHN H. JACKSON and ALAN SYKES

The completion of the Uruguay Round of negotiations has triggered the creation of international agreements which themselves raise issues of difficulty and importance in legal terms, as well as issues of practical importance for international trade in goods and services and for the entire field of Intellectual Property Rights. This book, written by experts from all over the globe, regards the implementation of the GATT agreement, and its national and international legal and constitutional ramifications.

$1997 \$ 145.00$
International Law Concerning Child Civilians in Armed Conflict JENNY KUPER

Each year, thousands of children are injured or killed as a result of armed conflicts. Although there is a considerable body of international law aimed at reducing the harm inflicted on these children, little of it is known or observed. This book, the first major text to focus exclusively on child civilians, increases awareness and observance of relevant laws in order to improve the protection of such children. 1997 paper $\$ 37.50$ cloth $\$ 90.00$

\section{Voluntary Euthanasia and the Common Law}

\section{MARGARET OTLOWSKI}

Here, Otlowski investigates one of society's most complex and controversial issues. She critically examines the criminal law prohibition of medically administered active voluntary euthanasia in common law jurisdictions, and carefully looks at the situation as handled in practice. An argument for legal reform is made with reference to the position in the Netherlands (where such euthanasia is now openly practiced).

$1997 \$ 135.00$

\section{New in paperback!}

\section{Philosophical Foundations of Tort Law}

\section{Edited by DAVID G. OWEN}

"This well-organized volume of essays testifies to an academic school's coming of age. In a generation, English-speaking scholars have generated a literature on the foundations of tort law that is unique in legal history. This introduction to the field invites readers to join the ongoing debates between the philosophers and the economists and between those who believe in the neutrality of justice and those who assert the inevitably partisan nature of law." - George P. Fletcher, Columbia University 1996 (paper 1997) paper $\$ 29.95$ cloth $\$ 75.00$

\section{The Concept of International Obligations Erga Omnes MAURIZIO RAGAZZI}

This is the first monograph on the idea of obligations erga omnes, an increasingly important concept in contemporary international law. Ragazzi employs a pragmatic approach that identifies five common elements among the examples of obligations erga omnes given by the International Court. These five properties are then discussed comparatively.

$1997 \$ 100.00$ 


\section{Important International Law Titles from...}

\section{UNDERSTANDING CHINESE COURTS AND LEGAL PROCESS: LAW WITH CHINESE CHARACTERISTICS \\ by Ronald C. Brown}

In order to cope with the legal challenges presented by the opening of the Chinese economy to the West, the legal system in China has been undergoing significant reform. In 1995 a new Judge's law came into effect after going through 30 draft revisions. This new law provided for sweeping changes in Chinese legal process. The author of this volume presents an overview of these important legal reforms and explains what they mean for Westerners operating in China.

August 1997, Hardbound, 448 pp., ISBN: 90-411-0607-3, \$135.00

\section{SOVEREIGNTY THROUGH INTERDEPENDENCE}

by Harry Gelber

Is it true that the forces of technology and interdependence have undermined the sovereignty of modern states? This book argues powerfully that the opposite is true: that over the last twentyfive years the major industrial states have mostly used these forces to pursue national purposes. The nation-state framework has, over this period, remained the basis of legitimate political authority and law. There has been a huge increase in the scope, incidence and detail of states' regulation to manage, among other things, the domestic economy and the effects of trans-national flows. The author takes strong issue with much of the literature on interdependence and international organisation which has appeared in recent times. This book is an invaluable source of reference for anyone trying to understand the dynamics of contemporary international relations.

May 1997, Hardbound, Pages: 368, ISBN: 90-411-0946-3, $\$ 115.00$

\section{CASES AND MATERIALS ON TERRORISM}

Three Nations' Response

edited by Micbael F. Noone \& Yonab

Alexander

This book fills an important gap in the literature on terrorism. It is designed as a case book, induding seminal cases which set out the fundamental rules or principles applicable when circumstances are sufficiently intense to warrant use of the term 'terrorism'. The United Kingdom is used as a primary source because English law regulating political violence has been continually refined and has served as a paradigm for other countries that derive their jurisprudence from that experience. Ireland represents what might be called the post-revolutionary variation. Its laws were drafted and are administered by those who clearly recall the successes and failures of the British campaigns in their country. The U.S. presents a third, peaceful model and a country which is increasingly confronted by terrorist acts. The themes addressed revolve around legal efforts to reconcile security considerations with those liberal democratic values which the nations consider to be their constitutional heritage.

May 1997, Hardbound, Pages: 576,

ISBN: 90-411-0278-7, \$217.00

\section{FROM OCCUPATION TO INTERIM \\ ACCORDS: ISRAEL AND THE PALESTINIAN TERRITORIES \\ by Raja Shebadeb}

This book presents an in-depth legal analysis of the lengthy and complicated agreements signed between Istael and the PLO. The legal and administrative developments that took place in the Palestinian areas over the past twenty years are surveyed and closely analyzed, providing the background essential to an understanding of the agreements signed between Israel and the PLO.

August 1997, Hardbound, Pages: 315, ISBN: 90-411-0384-8, $\$ 130.00$ 


\section{KLUWER LAW INTERNATIONAL}

HUMAN RIGHTS AND THE ADMINISTRATION OF JUSTICE International Instruments edited by Christopher Gane \& Mark Mackarel

This text seeks to provide the legal practitioner, academic and student with the materials that reveal the extent of human rights protection, the procedures for bringing a complaint and the way in which the protection of human rights are incorporated into judicial procedures.

Key human rights documents are introduced with an overview of the development and operation of human rights protection, and subsequent texts carry introductory notes.

July 1997, Hardbound, Pages: 837, ISBN: 90-411-0693-6, \$248.00

IN SEARCH OF OPEN SKIES: LAW AND POLICY FOR A NEW ERA IN INTERNATIONAL AVIATION A Comparative Study of Airline Deregulation in the United States and European Union by Brian F. Havel

This book is an important contribution to the open skies debate in international aviation. It breaks new ground in its comparative treatment of US and EU airline deregulation and exposes the anticompetitive bias of the archaic regime of bilateral air transport treaties launched over fifty years ago at Chicago. Repudiating bilateralism, it interweaves the successes and limitations of the US and EU air transport liberalization programs to define a 21st century multilateral open skies solution that poses intellectual challenges to all whose mission is the evolution of new law and policy for the international air transport industry.

June 1997, Hardbound, Pages: 560, ISBN: 90-411-0353-8, \$183.00

\section{INTERNATIONAL INTELLECTUAL}

\section{PROPERTY LAW}

edited by Antbony D'Amato $\mathcal{E}$

Doris Estelle Long

International intellectual property law is a vast and burgeoning field that cannot be covered by a single author. This book collects and organizes works by some of the best current authors in the field and supplements their work by numerous essays and notes prepared by the editors. The controlling provisions of the major treaties in the field are included in a comprehensive Appendix. The result is a book that is perhaps the most up-to-date and authoritative single-volume treatise on international intellectual property.

July 1997, 687 pp., $\$ 152.00$

\section{UNITED STATES ADMIRALTY LAW \\ by Gerard J. Mangone}

This work analyzes the development of maritime law across the centuries and its adoption into the United States Constitution from England as admiralty law. It gives explanations of the meaning of jurisdiction and the law appropriate for the carriage of goods by sea, personal injuries and death collisions, salvage and wrecks, marine insurance, and marine pollution. The style is succinct and readable, with sufficient but not exhaustive references to statutes, conventions, and law cases, including some historical and social background to enliven and clarify the development of admiralty and maritime law in the U.S.

June 1997, Hardbound, Pages: 328, ISBN: 90-411-0417-8, \$121.00

Please visit our web site at www. kluwerlaw. con

675 Massachusetts Avenue $\bullet$ Cambridge, MA 02139 (617) 354-0140 • Fax: (617) 354-8595• sales@kluwerlaw.com 


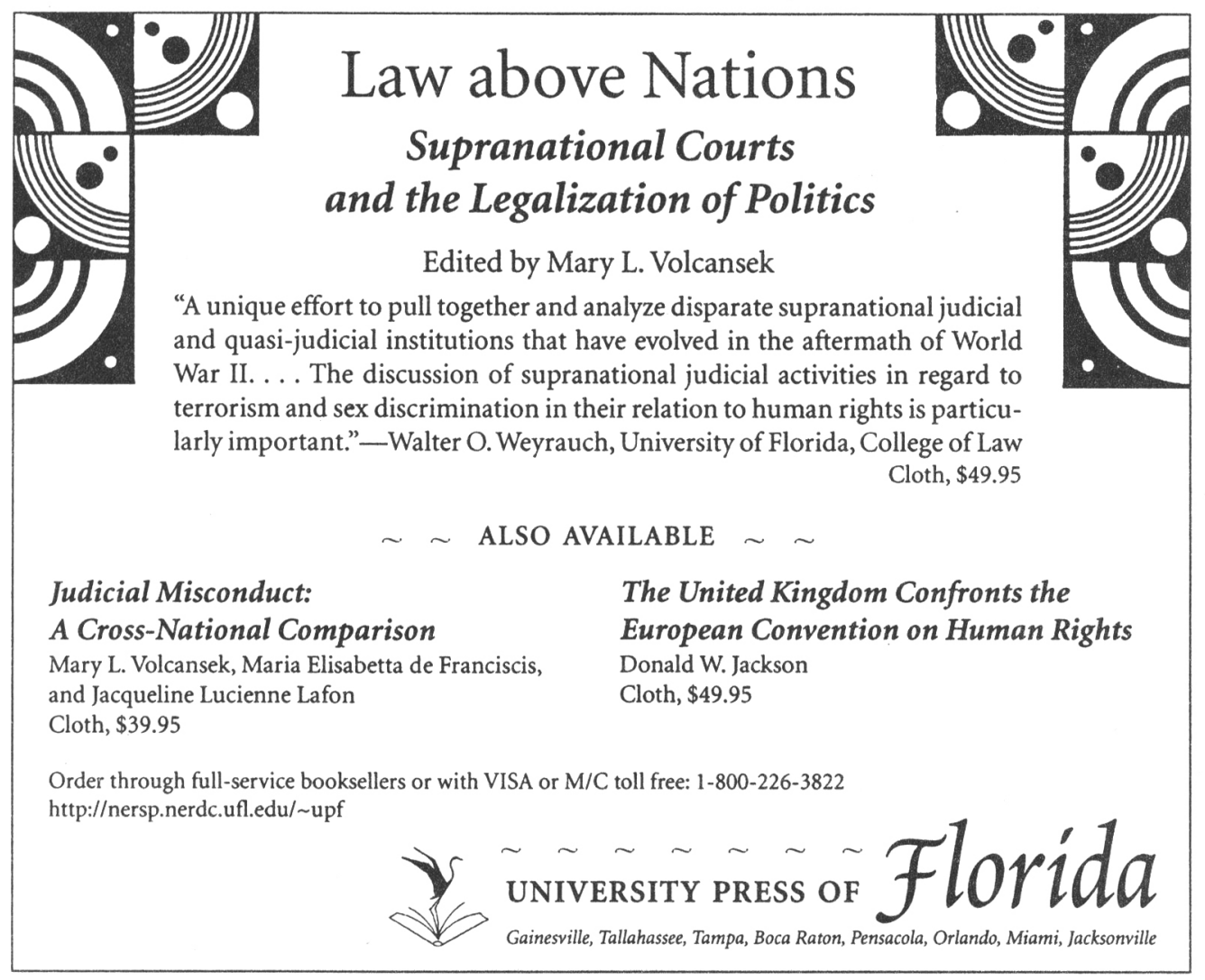

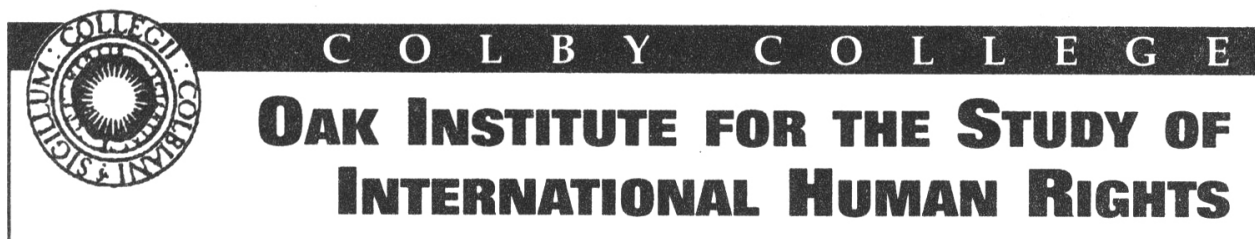

The Oak Foundation for the Study of International Human Rights at Colby College is soliciting nominations for the first Oak Fellow. The fellowship provides an opportunity for a prominent practitioner in international human rights to take a sabbatical from his or her work and spend a period of up to a semester as a scholar-in-residence at the College. The Oak Fellow's responsibilities include participation in a class or section of a class with a Colby faculty member and assistance in shaping a lecture series or symposium associated with the particular aspect of human rights of interest to the Fellow. The Fellow would be expected to participate in the intellectual life of the campus and enable our students to study or work with a professional in the field.

The Fellow will receive a stipend and College fringe benefits plus round-trip transportation from the Fellow's home site, housing for a family, use of a car, and meals on campus. The Fellow will also receive research support including office space, secretarial support, computer and library facilities, and a student research assistant.

Nominations for Oak Fellows for the 1998-99 academic year should be sent to Professor Kenneth Rodman, Government Department, Colby College, Waterville, Maine 04901 (fax: 207-872-3263; e-mail: karodman@colby.edu) as soon as possible but no later than February 1, 1998. After careful review of the nominations, our selection committee may ask finalists to send additional information. Final selections will be announced early in the Spring 1998 semester. Colby is an $A A / E O E$ and encourages applications from women and minorities. 


\section{The Facts You Need at Your Fingertips}

Published bimonthly since 1962 , ILM provides the basic, primary documents of research and analysis. Materials are selected for their usefulness to scholars, practitioners, business and government officials, both in the U.S. and abroad. Each 250-page issue contains the full texts of important treaties and agreements, judicial and arbitral decisions, national legislation, international organization resolutions and other documents.

A content summary precedes each document, many of which are accompanied by authored introductions. Status information for treaties also appears in each issue.

\section{Order Form}

Member Subscription:

$$
\$ 95 \text { (domestic) }
$$

Non-Member Subscription:

$\$ 190$ (domestic)

Name

Address

City

State

Zip

Country

Phone

Fax

E-mail

\section{Payment}

$\square$ Check payable to ASIL (check must be drawn in US funds on a US bank)

$\square$ American Express $\square$ VISA $\square$ MasterCard

Name

Card Number

Exp. Date

Signature

Fax credit card orders to: (202) 797-7133

Mail to: ASIL, PO Box 0164

Washington, DC 20055-0164 USA

Call: (202) 939-6000 


\section{The Role of Law in International Politics}

An interdisciplinary conference organised by the

International Law Association (British Branch)

in co-operation with the

Centre for International Studies, Oxford University

Centre for Socio-Legal Studies, Oxford University

\section{4-25 April 1998 \\ Rhodes House, Oxford}

Speakers include:

Eyal Benvenisti, Hebrew University

Alan Boyle, University of Edinburgh James Crawford, Cambridge University

Andrew Hurrell, Oxford University

Benedict Kingsbury, Duke University

Martti Koskenniemi, University of Helsinki

Friederich Kratochwil, University of Munich

Neil MacFarlane, Oxford University

Georg Nolte, Max-Planck-Institute for International Law

Stephen Toope, McGill University

Adam Roberts, Oxford University

Anne-Marie Slaughter, Harvard University

Brigitte Stern, University of Paris

Sir Arthur Watts

\section{Sponsored by the Foreign \& Commonwealth Office}

For more information and a registration form, please contact:

Dr Michael Byers

Jesus College, Oxford, OX1 3DW, United Kingdom

Fax: +44 1865279687

E-mail: michael.byers@Jesus.ox.ac.uk 


\section{IHE BEST WN LAW FROM CAMBRIDGE}

\section{International Law}

Fourth Edition

\section{Malcolm Shaw}

The fourth edition of Malcolm Shaw's bestselling textbook in international law represents a major revision of its predecessor. Alongside substantial new chapters dealing with human rights and the United

\section{ITIERMITIONAL LATI} Nations, Shaw has incorporated new material on international environmental law, state succession, recog nition, the settlement of disputes by peaceful means and international

institutions. Above all the book remains a comprehensive and highly readable introduction to international law.

\section{4-0 Hardback \$155.00 \\ 57667-9 Paperback \$49.95}

\section{Unjust Enrichment}

A Study of Private Law and Public Values

\section{Hanoch Dagan}

"Hanoch Dagan's new book on unjust enrichment is the best in the field in many years. It reflects Professor Dagan's sure mastery of all the relevant doctrine and his understanding of contemporary methods of philosophic and economic analysis. In applying these new methods to the old doctrines, Dagan has illuminated this important area of law in an original and bighly provocative way."

- Anthony T. Kronman,

Yale Law School

Cambridge Studies in International and Comparative Law

58468-X Hardback \$59.95

\section{Trade and the} Environment

A Comparative Study of EC and US Law Damien Geradin

Trade and the Environment is a penetrating analysis of the relation between trade and environmental protection policies in the European Community and the United States. It argues that the international tensions arising from policies designed to protect trade and the environment can be resolved by the free trade provisions of the EC Treaty and the US Constitution, and from the setting of common environmental standards for all parties. Cambridge Studies in International and Comparative Law

59012-4 Hardback \$69.95

\section{Manual of European Environmental Law}

\section{Second Edition}

\section{Alexandre Charles Kiss and Dinah Shelton}

This manual, now revised and updated for its second edition, provides a detailed overview of the complex and distinct body of European environmental law. Written for a multi-disciplinary audience, the book will prove of value to the legal, business and scientific practitioner or researcher, as well as to all those interested in environmental law, science and policy.

$\begin{array}{lll}59122-8 & \text { Hardback } & \$ 125.00 \\ 59888-5 & \text { Paperback } & \$ 59.95\end{array}$

\section{International Law Reports \\ Volume 105 \\ E. Lauterpacht, C.J. Greenwood, and Andrew Oppenheimer, Editors 58067-6 Hardback \$140.00}

Available in bookstores or from

CAMBRIDGE UNIVERSITY PRESS
40 West 20th St., N.Y., NY 10011-4211. Call toll-free 800-872-7423. MasterCard/VISA accepted. Prices subject to change. Web site: http://www.cup.org 


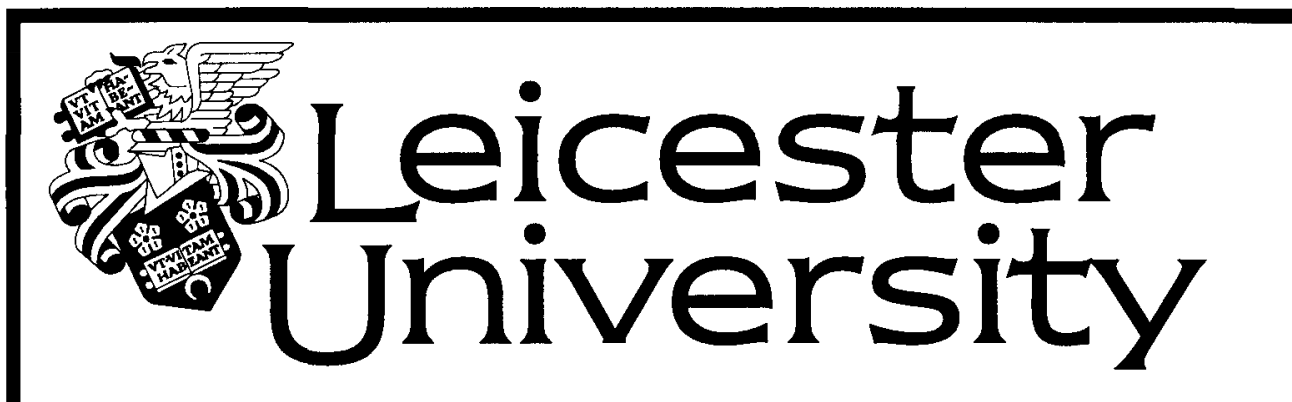

\section{GRADUATE SCHOOL OF LAW}

Promoting excellence in University teaching and research

The University gained its Royal Charter in 1957. Leicester, a city located in England's central region is Britain's first Environment City and a thriving cosmopolitan community of 300,000 .

The School's one-year modular Masters' programmes have been constructed on the basis of the strengths of Faculty staff who have national and international reputations as researchers at one of the leading law schools in the United Kingdom. The School's teaching and research have achieved high ratings in national assessment exercises. The Graduate School offers:

- small group teaching emphasizing research skills

- modern library and computer facilities

- accommodation situated close to the campus

- visits from distinguished international guest lecturers

- assessment by coursework and dissertation

\section{LL.M in Human Rights and Civil Liberties}

Core module on foundations of human rights plus options including the European Convention on Human Rights, Freedom of Expression, Religions, Rights and Laws, International Protection of Rights of Migrants, Global Protection of Human Rights, Mental Health, Prisoners' Rights, Law and Terrorism.

\section{LL.M Programme in European Higher Legal Studies}

This is an innovative two-year full time programme. The first year is spent at Leicester followed by consecutive sixth month periods at two other partner Universities spread among eleven European Countries.

\section{LL.M in European and International Trade Law}

Options include: Commercial Conflict of Laws, Law and Organisation of the World Trading System, Competition law, Constitutional and Economic Law of the European Union, The European Union as an International Actor, International Regulation of Companies, International Exploitation of Intellectual Property Rights, International Trade and Cultural Property, Trade, Investment and Development, Copyright in the European Union, International Sales, International Carriage of Goods, State Intervention and Utilities Regulation in the European Union.

Brochure (please specify programme) and application form available from:

The Postgradúate Admissions Secretary

Faculty of Law, University of Leicester, LEICESTER LE1 7RH

United Kingdom

Tel: $+44(0) 1162522753$

Fax: + $44(0) 1162525023$

Electronic Mail: jmg16@le.ac.uk

Telex: 347250 Leicun G. Home Page: http://www.le.ac.uk/law/ 


\title{
HUMANITARIAN INTERVENTION
}

\author{
The United Nations in an Evolving World Order
}

\author{
Sean D. Murphy
}

\section{Winner of the American Society of International LaW Certificate for Preeminent Contribution to Creative Scholarship}

Over the centuries, societies have developed constraints on the use of armed force in the conduct of foreign relations. The crowning achievement of these efforts occurred in the mid-twentieth century with the general acceptance that the use of military force for territorial aggrandizement was unacceptable.

A central challenge for the next century rests in reconciling these constraints with the increasing desire to protect innocent persons from the human rights deprivations that often take place during civil war or result from persecution by autocratic governments. Should states be allowed to intervene militarily in the affairs of other states to prevent human rights deprivations-an action commonly referred to as "humanitarian intervention?" If so, under what conditions should such intervention occur?

Humanitarian Intervention addresses these fundamental questions through an in-depth look at the historical development of contraints on the use of force and at incidents of humanitarian intervention prior to, during, and after the Cold War. The first comprehensive study of this issue since the interventions in Bosnia, Haiti, Iraq, Liberia, Rwanda, and Somalia.

Sean D. Murphy is Counselor for Legal Affairs, U.S. Embassy at The Hague.

“This is a work of exceptional Quality. Without Doubt, Murphy HAS WRUTTEN THE BEST BOOK ON THE TOPIC OF HUMANITARIAN INTERVENTION. IT IS COMPREHENSIVE, BALANCED, AND ALIVE TO NUANCE AND COMPLEXITY, PROVIDING AN INVALUABLE GUIDE BOTH TO RECENT UN PEACEKEEPING EFFORTS AND TO THE EVOLVING ROLE OF INTERNATIONAL LAW WITH RESPECT TO THE USE OF FORCE. IDEAL BOTH FOR USE IN COURSES AND FOR SPECIALISTS." -Richard Falk, Princeton University.

Volume 21 of the Procedural Aspects of International Law Book Series 


\section{International Committee of the Red Cross (ICRC) Joint Training Seminars for University Teachers on International Humanitarian Law}

The ICRC, assisted by a generous grant from the Hauser Foundation, will hold two training seminars on International Humanitarian Law (IHL) for full-time university teachers already teaching public international law or human rights and who are ready to make a commitment to teach $\mathrm{IHL}$ in their universities.

The first seminar, held jointly with the Graduate Institute of International Studies, will take place in Geneva on 10-15 August 1998 (arrival August 9, departure August 16).

The second seminar, held jointly with the New York University Law School, will take place in New York City during the summer of 1999.

The co-directors of the seminars will be Professor Theodor Meron of NYU Law School and Mr. Antoine Bouvier of the ICRC. The language of instruction will be English. Instructors will be experts from academia, ICRC and practice. The seminars will cover $\mathrm{IHL}$ and relevant aspects of human rights law applicable in international and internal armed conflicts (including historical development, types of conflicts, Geneva law, The Hague law (law on the conduct of hostilities), prisoners of war, occupation, humanitarian assistance, customary law, war crimes and responsibility), the place of IHL in general international law and teaching methods. Each participant will be provided with a coursebook to assist his/her future teaching.

The organizers will provide the participants with APEX type airfare to Geneva and living expenses in Geneva.

Applications for the 1998 seminar in Geneva, including full CVs and list of publications, statements explaining the candidates' interest and plans for teaching IHL, and two recommendations, must reach Mrs. Isabelle Gerardi, Graduate Institute of International Studies, 132 Rue de Lausanne, P.O. Box 36, 1211 Geneva 21, Switzerland, by January 31, 1998. Places are limited to thirty participants. Applicants will be notified by the end of March 1998 of the results of their applications. 


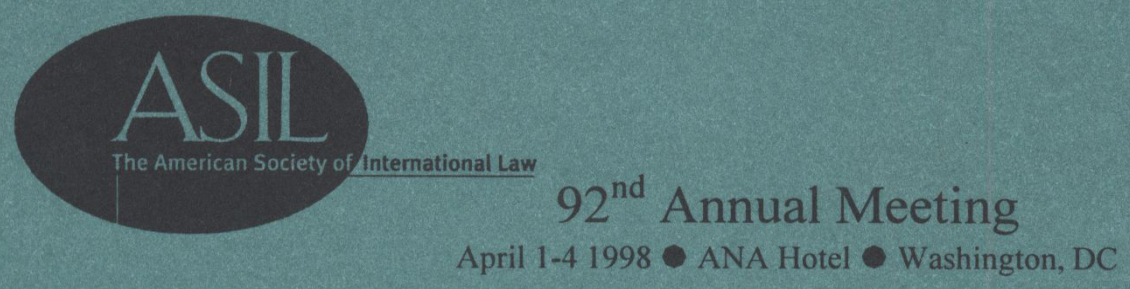

\section{The globalization of financial markets...Changing actors and obligations...Implications of today's new technology...}

These challenges are changing the way we practice law and manage world relations.

You can discover how these issues will affect you, your career, and our world at ASIL's 92nd Annual Meeting. More than 1,000 lawyers, law professors, and law students will gather in April to analyze these issues and many more.

Get the latest information on...

- Genocide

- WTO Enlargement

- War Crimes Tribunals

- International Environmental Decision Making
- Cultural Differences in Interpreting International Law

- International Security

- The European Nation

- And much more.

\section{Who Should Attend ASIL's Annual Meeting?}

- Any attorney who practices international law

- International law professors or anyone instructing on international issues

- Students interested in international law

- In-house legal counsel for multinational corporations

- Anyone specializing in immigration, arms control, human rights, or any other international political or social issue

Special Rates for Practitioners Working for Non-Profit and Governmental Organizations!

For more information about ASIL's Annual Meeting, the Society or membership information, please contact the Services Group at (202) 939-6000. Or, visit our Web site at www.asil.org. 